\title{
Isolation of 11 new polymorphic microsatellites from CA enriched turkey genomic libraries (Short communication)
}

\author{
EDIT KOROM ${ }^{1 *}$, KATALIN BAKOS ${ }^{*}$, GYULA VERESS ${ }^{1}$, ORSOLYA PINKE ${ }^{1}$, KENT M. REED², \\ LÁSZLÓ VARGA' and BALÁZS KOVÁCS'
}

${ }^{1}$ Agricultural Biotechnology Center, Gödöllö, Hungary, ${ }^{2}$ Department of Veterinary and Biomedical Sciences, University of Minnesota, Saint Paul, USA

\begin{abstract}
Microsatellite loci from the ancient Hungarian variety of the Broad Breasted Bronze Turkey (Meleagris gallopavo) were isolated. CA-repeat enriched libraries were constructed from DNA of randomly collected samples. Libraries were screened for repeat-containing clones by PIMA (PCR Isolation of Microsatellite Arrays) and the DNA-sequence of 167 positive clones was determined. A total of 136 microsatellite repeat-containing sequences were found, 59 sequences were unique. Comparing these with the genomic databases, we found 7 previously annotated microsatellite sequences. The newly isolated 52 microsatellites were tested on the mapping population of the University of Minnesota, and the map position of 11 microsatellites was determined.
\end{abstract}

Keywords: turkey (Meleagris gallopavo), microsatellite isolation, CA-enriched, genomic library, magnetic beads, PIMA

\section{Zusammenfassung}

\section{Isolierung von 11 neuen polymorph dinukleotid Mikrosatelliten von CA angereicherten Truthahn Genombibliotheken (Kurzmitteilung)}

Bei Tieren einer alten ungarischen Variante der breitbrüstigen Bronzepute wurden Mikrosatelliten isoliert. Aus der DNA zufällig erfasster Proben wurden wiederholt CA angereicherte Genombibliotheken hergestellt. Die durch Wiederholung enthaltenen Klone der Gesamtbibliotheken wurden mit Hilfe der PIMA (PCR Isolation of Microsatellite Arrays) erfasst und die DNA-Sequenz von 167 positiven Klonen bestimmt. Gefunden wurden 136 Mikrosatelliten der angereicherten Sequenzen von denen 59 Einzelsequenzen waren. Diese wurden mit Genom Datenbanken verglichen und es konnten 7 bereits bekannte gefunden werden. Die 52 neu isolierten Mikrosatelliten wurden an der Genbank der Universität von Minnesota überprüft und die Zuordnung von 11 Mikrosatelliten wurde bestimmt.

Schlüsselwörter: $\quad$ Pute (Meleagris gallopavo), Mikrosatelliten-Isolation, CA angereicherte Genombibliothek, magnetische Perlen, PIMA 


\section{Introduction}

Development and application of genetic markers in turkey (Meleagris gallopavo) began in the mid 1990's (HUANG et al. 1999, LEVIN et al. 1995, SMITH et al. 1996b). Different methods of random genome analyses such as randomly amplified polymorphic DNA (RAPD), single primer amplification of simple sequence repeats (SPARS), and application of chicken and turkey microsatellites were used to estimate genetic diversity within the species (SMITH et al. 1996a). However, because of low allelic variation and heterozygosity in their test populations, LIU et al. (1996) concluded that chicken loci would be of little use in constructing a turkey map. At the same time avian genomes were reported to contain a lower number of microsatellites (ms), compared to mammals (PRIMMER et al. 1997) seemingly complicating the discovery of turkey-specific markers. Despite the slow start and the problems associated with turkey genome mapping, considerable progress was made in both marker development and construction of a comprehensive genetic map. An integrated genetic map of the turkey was prepared containing 613 loci in 41 linkage groups with a total length of $3365 \mathrm{cMs}$ (REED et al. 2007) and the turkey genome programme is also in progress. Here we report the isolation of 52 dinucleotide sequences from the ancient Hungarian variety of the Broad Breasted Bronze Turkey (Meleagris gallopavo) with the characterisation and mapping of eleven new loci.

\section{Material and methods}

For microsatellite isolation and characterization DNA was isolated from blood samples of 10 individuals of the Hungarian variety of the Broad Breasted Bronze turkey with a simple salting out procedure (MILLER et al. 1988). These individuals were selected on the basis of genetic variability, according to previous results (SZÖKE et al. 2004). CA-repeat enriched libraries were constructed following the protocol of GLENN and SHABLE (2005). Three female DNA samples from the 10 were digested with restriction endonucleases: Rsa I. (Fermentas) and Hae III. (Fermentas), followed by isolation with the biotinilated oligonucleotide ((CA) ${ }_{18}{ }^{-}$ biotin), streptavidin-coated magnetic particles (Dynabeads) and KBB1 linkers (KBB1 forward: 5' AGG TAC CAG CCA TAT GGG CAG CAT GC 3'; KBB1 reverse: 5' CAT GCT GCC CAT ATG GCT GGT ACC TAA A $3^{\prime}$ ). Isolated fragments were cloned into a vector (pGEM-T Easy, Promega) and transformed into competent cells (XL1 Blue). Cells were grown on LB agar supplemented with ampicillin $(150 \mu \mathrm{g} / \mathrm{ml})$, IPTG $(20 \mu \mathrm{g} / \mathrm{ml})$ and X-Gal $(40 \mu \mathrm{g} / \mathrm{ml})$.

Insert-containing colonies chosen on the basis of blue-white selection and were screened with PCR Isolation of Microsatellite Arrays (PIMA) consisting of two reactions: first using transforming vector-specific primers M13 Forward and Reverse primers only (reaction contained: 200nM each primer, $2 \mathrm{mM} \mathrm{MgCl2;} 320 \mathrm{nM}$ dNTP; $1 \mathrm{U}$ Taq polymerase, Roche) and a second reaction containing an additional primer (CA primer: $5^{\prime}$ ACA CAC ACA CAC ACA CDN $3^{\prime}$ ) specific for the repeat (200nM each primer, $2 \mathrm{mM} \mathrm{MgCl2;320nM} \mathrm{dNTP;} 1 \mathrm{U}$ Taq polymerase, Roche), supplemented with $4 \%$ DMSO (LUNT et al. 1999). In case of repeat containing clones the second reaction gives two bands. The transformed colonies were used as templates. Amplifications were performed in an Applied Biosystems 9700 thermal cycler and the reaction profile was: 3 cycles of $95^{\circ} \mathrm{C}$ for $2 \min , 45^{\circ} \mathrm{C}$ for $1 \mathrm{~min}, 72^{\circ} \mathrm{C}$ for $1 \mathrm{~min} 15 \mathrm{~s}$, followed by 41 cycles of $95^{\circ} \mathrm{C}$ for $30 \mathrm{~s}, 45^{\circ} \mathrm{C}$ for $30 \mathrm{~s}, 72^{\circ} \mathrm{C}$ for $1 \mathrm{~min} 15 \mathrm{~s}$, then $72^{\circ} \mathrm{C} 5 \mathrm{~min}$. PCR products were visualized on $2 \%$ agarose gels stained with ethidium bromide. If a 
fragment smaller than the insert was also detected in the second reaction, the sequence of the insert was determined. Sequencing was performed in an ABI Prism 310 Genetic Analyser using ABI Prism Big Dye Terminator 3.1 kit. Sequences were compared with each other and the NCBI database and primers were designed for unique sequences with the OligoExplorer programme.

Microsatellite primers were tested on the 10 Broad Breasted Bronze turkeys and mapping was done on the F1 and F2 generation of the mapping population of the University of Minnesota (UMN/NTBF, REED et al. 2003). PCR reactions included $25 \mathrm{ng}$ genomic DNA, $2 \mathrm{mM}$ dNTP (Roche), $720 \mathrm{nM}$ forward and reverse primers, $2000 \mathrm{ng}$ BSA and 0,2 U Taq polymerase (Roche). Amplifications were performed with the following reaction conditions: $94^{\circ} \mathrm{C} 6 \mathrm{~min}$; 10 cycles of $94^{\circ} \mathrm{C} 30 \mathrm{~s}, 63-56^{\circ} \mathrm{C}$ or $60-53^{\circ} \mathrm{C} 30 \mathrm{~s}, 72{ }^{\circ} \mathrm{C} 45 \mathrm{~s} ; 30$ cycles of $94^{\circ} \mathrm{C} 30 \mathrm{~s}, 56^{\circ} \mathrm{C}$ or $53^{\circ} \mathrm{C} 30 \mathrm{~s}, 72^{\circ} \mathrm{C} 45 \mathrm{~s}$ and $72^{\circ} \mathrm{C} 5 \mathrm{~min}$. Products were run on denaturing acrylamide gels (50 $\mathrm{cm} \times 38 \mathrm{~cm} \times 0.4 \mathrm{~mm}$ ) using a Sequi-Gen GT Sequencing Cell (BIORAD) and fragments were visualized by silver staining (VARGA et al. 1997). Genotypes of loci genetically informative in the mapping families were determined by PAGE and detected with ${ }^{32}$ P-labeled nucleotides and autoradiography. The map position of the microsatellite loci were determined using Locusmap software (GARBE and DA 2003).

\section{Results and discussion}

We constructed a CA-enriched turkey genomic library. After screening, the DNA-sequence of 167 positive clones was determined, all of them contained CA-repeats, 136 were typical microsatellites sequences.

Comparing these sequences with each other, 59 unique sequences were found, 7 of them were previously annotated in GenBank (NCBI). Primers were designed for the newly isolated 52 microsatellies and tested on the 10 Broad Breasted Bronze turkey samples and on the UMN/NTFB mapping families (University of Minnesota).

A total of eleven markers were found to be genetically informative in the mapping families. LOD scores ranged from 3.54 to 40.08 (Table 1). Two markers (MGP40 and MGP46) on turkey chromosome 1 (MGA1) were linked at a distance of $14.95 \mathrm{cM}(\mathrm{LOD}=7.51)$ as were two of the markers (MGP18 and MGP 35) on MGA 2 (distance=26.84 cM, LOD=9.16). The addition of MGP47 and its linkage with the chicken microsatellite ADL184 allowed for identification of the new linkage group MGA35 that is homologous to GGA18 (REED et al. 2007). The turkey genome project (DALLOUL et al. 2010) revealed the chromosomal position of the markers too (Table 1).

The efficiency of microsatellite enrichment was very high (100\%), however it led to redundancy. The observed number of alleles was nearly similar in the Broad Breasted Bronze turkeys and in the mapping population. Compared to other studies on turkey microsatellites, the number of detected alleles was comparable, but the number of monomorphic markers was higher (REED et al. 2003, BURT et al. 2003), whereas the microsatellites were tested only on Broad Breasted Bronze turkey individuals from an inbred stock and on the UMN/NTBF mapping population. Domestic turkeys generally show significantly reduced numbers of alleles per locus when compared to wild turkeys (LATCH et al. 2002). Position of monomorphic microsatellites can further be determined on the basis of the turkey genome sequence (DALLOUL et al. 2010) and can be polymorphic and usable in other populations. 


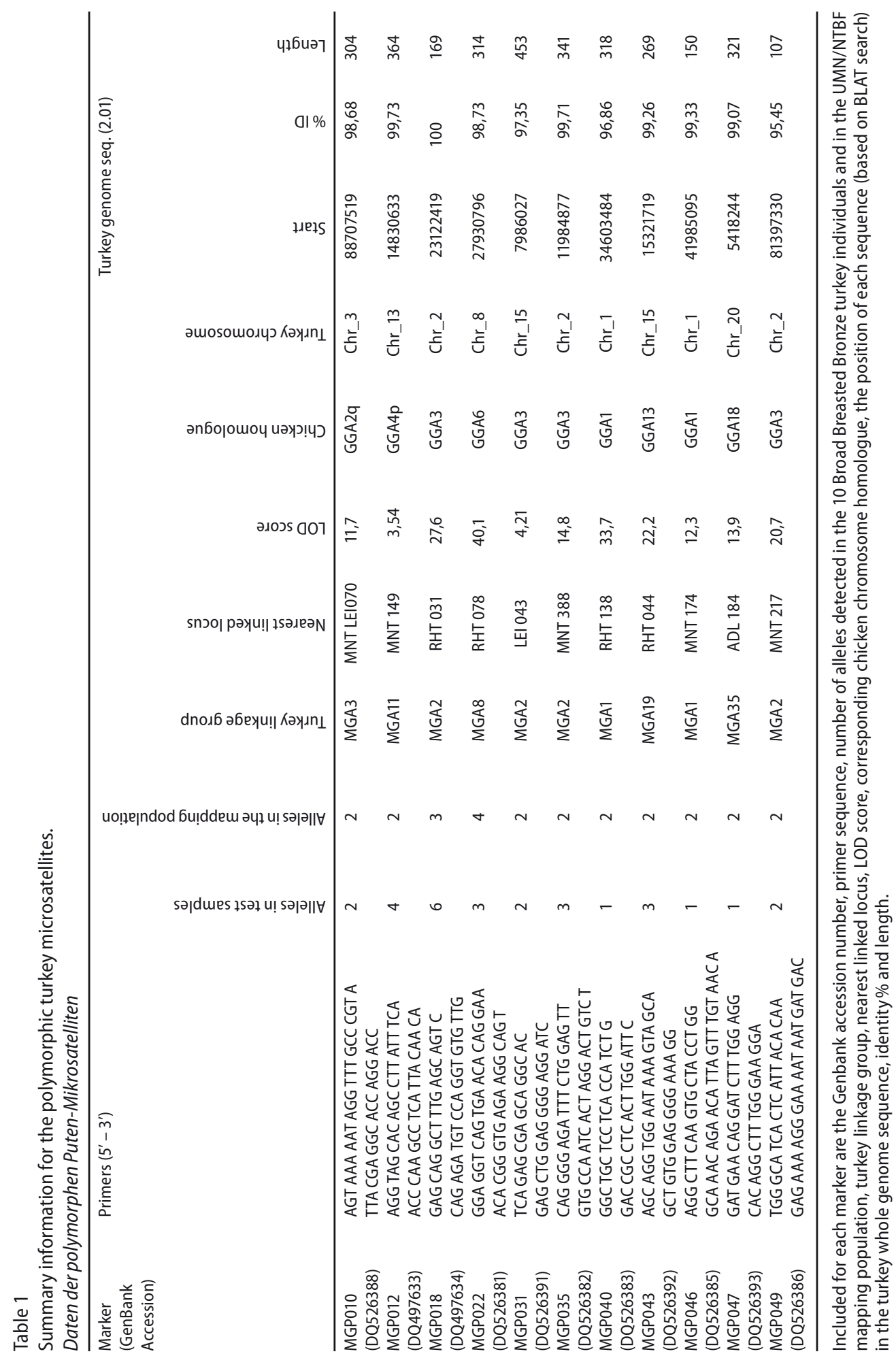




\section{Acknowledgements}

The authors thank the Hungarian National Research Fund (OTKA PD 79711) and a Bolyai Research Fellowship of the Hungarian Academy of Sciences.

\section{References}

Burt DW, Morrice DR, Sewalem A, Smith J, Paton IR, Smith EJ, Bentley J and Hocking PM (2003) Preliminary linkage map of the Turkey (Meleagris gallopavo) based on microsatellite markers. Anim Genet 34, 399-409

Dalloul RA, Long JA, Zimin AV, Aslam L, Beal K et al. (2010) Multi-Platform Next-Generation Sequencing of the Domestic Turkey (Meleagris gallopavo): Genome Assembly and Analysis. Plos Biol 8 (9): e1000475

Garbe KJ, Da Y (2003) Locusmap user manual Version 1.1. Department of Animal Science, University of Minnesota, St. Paul. Glenn TC, Schable NA (2005) Isolating microsatellite DNA loci. Methods in Enzymol $395,202-22$

Glenn TC, Schable NA (2005) Isolating microsatellite DNA Loci. Methods Enzymol 395, 202-22

Huang HB, Song YQ, Hsei M, Zahorchak R, Chiu J, Teuscher C, Smith EJ (1999) Development and characterization of genetic mapping resources for the turkey. J Hered 90, 240-2

Latch EK, Smith EJ, Rhoade OE Jr. (2002) Isolation and characterization of microsatellite loci in wild and domestic turkeys (Meleagris gallopavo). Mol Ecol Notes 2, 176-8

Levin I, Cheng HH, Baxter-Jones C, Hillel J (1995) Turkey microsatellite DNA loci amplified by chicken-specific primers. Anim Genet 26, 107-10

Liu Z, Crooijmans RPMA, van der Poel JJ, Groenen MAM (1996) Use of chicken microsatellite markers in turkey: A pessimistic view. Anim Genet 27, 191-3

Lunt DH, Hutchinson WF, Carvalho GR (1999) An efficient method for PCR based isolation of microsatellite arrays (PIMA). Mol Ecol 8, 891-4

Miller SA, Dykes DD, Polesky HF (1988) A simple salting out procedure for extracting DNA from human nucleated cells. Nucleic Acids Res 16, 1215

Primmer CR, Raudsepp T, Chowdhary BP, Moller AP, Ellegren H (1997) Low frequency of microsatellites in the avian genome. Genome Res 7, 471-82

Reed KM, Chaves LD, Hall MK, Knutson TP, Rowe JA and Torgerson AJ (2003) Microsatellite Loci for Genetic Mapping in the Turkey (Meleagris gallopavo). Anim Biotechnol 14, 119-31

Reed KM, Chaves LD, Mendoza KM (2007) An integrated and comparative genetic map of the turkey genome. Cytogenet Genome Res 119(1-2), 113-26

Smith EJ, Jones CP, Bartlett J, Nestor KE (1996a) Use of randomly amplified polymorphic DNA markers for the genetic analysis of relatedness and diversity in chickens and turkeys. Poult Sci 75(5), 579-84

Smith EJ, Ray SA, Bakst MR, Teuscher C, Savage TF (1996b) Simple sequence repeat-based single primer amplification of genomic DNA in random bred populations of turkeys and chickens. Anim Biotechnol 7, 47-58

Szőke Sz, Komlósi I, Korom E, Ispány M, Mihók S (2004) A statistical analysis of population variability in Bronze Turkey considering gene conservation. Arch Tierz 47, 377-85

Varga L, Szabó Gy, Darvasi A, Müller G, Sass M, Soller M (1997) Inheritance and mapping of Compact (Cmpt), a new mutation causing hypermuscularity in mice. Genetics 147, 755-64

Received 7 July 2009, accepted 2 July 2010.

Corresponding author:

BALÁZS KOVÁCS

email: kovacs.balazs@mkk.szie.hu

Szent István University, Regional University Center of Excellence in Environmental Industry, Páter K. út 1, H-2100 Gödöllő, Hungary 